\title{
AKTUARI SEBAGAI PEGAWAI TERTINGGI KERAJAAN DARI PERSPEKTIF SEJARAH DAN ERA MODEN
}

\author{
Haslifah Mohamad Hasim
}

\begin{abstract}
Actuarius was a title applied to a high government official in the Ancient Roman Empire. The original duty of an actuarius was to record the proceedings of the Roman Senate. As time passed, the role of the actuarius continued to expand until the Eastern Roman Empire, or also known as the Byzantine Empire. At that time, the actuarius role in the government was not only limited to financial management but also involved in the distribution of wages to the Roman armies, military provisions and governmental policy-making. The historical background of actuaries, covering a span of over thousands of years, demonstrates the importance of actuarial science within the context of a country. In the $18^{\text {th }}$ century, the term actuary (which was derived from the Latin actuarius) was adopted by the Chief Official to refer to a position of a mathematician in a life insurance company. Over the past years, the demand for actuarial science continues to grow in various areas including in the public sector. Governments of some developed countries, such as the United States and the United Kingdom, started creating national actuarial posts to improve the formulation of economic and social development policies and to the country's leadership in general. In Malaysia, during the early days of the Federation of Malaysia, a qualified actuary was appointed and an Actuarial Services Unit was established under the Prime Minister's Department. But, unfortunately, after 50 years this unit has been abolished. In the modern era, many developed countries continue to recognise actuaries as high government officials who play key role in national development. However, this is not the case in the Malaysian context.
\end{abstract}

\section{Pengenalan}

Profesion aktuari bukan sesuatu yang baru. Hakikatnya, profesion ini telah pun wujud beribu tahun dahulu sejak zaman kegemilangan Empayar Rom Purba. Pada ketika itu, gelaran actuarius atau actuari - dalam Bahasa Latin yang membawa maksud pencatat minit mesyuarat atau pengurus akaun ${ }^{1}$ merupakan satu jawatan tertinggi kerajaan yang penting dan diberikan kepada pencatat minit dalam Senat Rom. Masa berlalu dan peranan aktuarius ${ }^{2}$ terus berkembang pada zaman Empayar Rom Timur yang dikenali sebagai Empayar Bizantium. Peranan aktuarius dalam kerajaan bukan sahaja terhad sebagai pengurus kewangan kerajaan tetapi turut terlibat dalam pengagihan gaji kepada tentera-tentera Rom, peruntukan ketenteraan serta membuat polisi dan dasar kerajaan. Pada zaman itu, aktuarius merupakan antara pegawai tertinggi kerajaan dalam kumpulan praetorian prefect, memainkan peranan penting dalam pentadbiran bersama pegawai-pegawai lain seperti numerarius (ketua akauntan), chartularius (pemegang rekod kerajaan) dan sebagainya.

Masa berlalu dan peranan aktuari terus berkembang di seluruh dunia termasuk di Malaysia. Aktuari menggunakan teori dan kaedah matematik dan statistik dalam bidangbidang berkaitan insurans nyawa dan am; bidang pencen dan keselamatan sosial; dan juga bidang pelaburan. Pada hari ini, gelaran aktuari terus sinonim dengan bidang insurans hayat. Ini dapat dilihat, contohnya di Malaysia, taburan profesion aktuari mengikut bidang menunjukkan sebahagian besar daripada mereka bekerja di bidang insurans hayat dan takaful keluarga iaitu sebanyak 70 peratus. Ini adalah untuk memenuhi keperluan di bawah Akta Insurans 1996 dan Akta Takaful 1984 yang mensyaratkan seorang aktuari bertauliah 
hendaklah dilantik oleh setiap syarikat insurans hayat dan pengendali takaful yang beroperasi di Malaysia.

Walaupun gelaran aktuari sinonim dengan bidang insurans hayat sejak abad ke-18 apabila sebuah syarikat insurans hayat iaitu Society for Equitable Assurances on Lives and Survivorships (dikenali sebagai Equitable Life) ditubuhkan di London, negara-negara maju telah mula mengikhtiraf profesion ini sebagai antara pegawai tertinggi kerajaan yang terlibat dalam perancangan ekonomi dan pelan pembangunan negara seperti mana pentingnya jawatan aktuarius di zaman Empayar Rom yang membantu dalam pentadbiran negara.

Justeru itu, objektif kertas ini adalah untuk membincangkan peranan aktuari sebagai pegawai tertinggi sesebuah kerajaan dari perspektif sejarah dan era moden.

\section{Sejarah Gelaran Aktuari}

Bahagian ini akan membincangkan secara terperinci bermulanya jawatan aktuarius pada zaman Empayar Rom Purba dan seterusnya peranan aktuarius sebagai pegawai tertinggi kerajaan yang terus berkembang di zaman Empayar Rom Timur.

\section{Aktuarius sebagai pencatat minit mesyuarat}

Perkataan aktuarius berasal daripada perkataan actum dalam Bahasa Latin yang membawa maksud dokumen kerajaan. Di zaman Empayar Rom Purba, aktuarius adalah satu jawatan penting yang bertugas sebagai pencatat minit senat Rom dan seterusnya menguruskan dokumen-dokumen kerajaan. Jebb (2002) yang mengkaji manuskrip-manuskrip ahli falsafah Rom, Plutarch memberi contoh perbahasan di dalam Senat Rom mengenai konspirasi Catiline di sekitar tahun 63 Sebelum Masehi dipercayai dicatat oleh seorang pegawai kerajaan bergelar aktuarius. ${ }^{3}$

Selain daripada tugas aktuarius sebagai pencatat minit senat Rom, jawatan aktuarius juga diberikan kepada pegawai kerajaan Empayar Rom untuk menguruskan rekod harian kerajaan. Rekod Acta Diurna mengandungi pelbagai berita termasuk politik, keputusan perbicaraan, jenayah dan ketenteraan. ${ }^{4}$ Sekitar tahun 59 Sebelum Masehi semasa pemerintahan Maharaja Julius Caesar (100-44 Sebelum Masehi) Acta Diurna dijadikan dokumen awam dan maklumat serta berita-berita semasa perlu disampaikan secara harian kepada rakyat. Di dalam menguruskan Acta Diurna, aktuarius dibantu oleh pegawaipegawainya yang terdiri daripada notarius (wartawan), scriba (pencatat minit di mahkamah) dan beberapa orang kerani.

Walaupun pada dasarnya aktuarius bertugas sebagai pencatat minit, peranan aktuarius sebagai ahli matematik adalah signifikan. Sebagai contoh, seorang aktuarius di zaman Empayar Rom Purba, seorang practorian prefect ${ }^{5}$ bernama Domitius Ulpianus (170-223 Masehi) telah berjaya menghasilkan jadual kemortalan yang pertama pada tahun 211 Masehi. ${ }^{6}$ Jadual kemortalan yang dikenali sebagai Jadual Ulpian ini menggunakan teori kebarangkalian dan kaedah matematik bagi menganggarkan jangka hayat rakyat Rom pada ketika itu. Jadual ini juga terkandung di dalam Kod Undang-undang Rom (atau dikenali sebagai Undang-undang Justinian) yang disusun oleh Maharaja Empayar Rom Timur, Justinian I (483-565 Masehi) dan digunakan dalam menyelesaikan pembahagian harta pusaka masyarakat Rom. Mengikut Undang-undang Falcidian, seseorang itu mesti meninggalkan sekurang-kurangnya satu-perempat daripada harta pusaka kepada waris yang sah. Harta pusaka ini dinilai dan diberikan kepada waris dalam bentuk anuiti tetap mengikut perkiraan jangka hayat berdasarkan Jadual Ulpian. Menurut Kopf (1926), Jadual Ulpian ini merupakan jadual kemortalan paling lama digunakan dalam sejarah sains aktuari iaitu masih digunakan oleh Kerajaan Tuscan sehingga ke tahun $1814 .^{7}$

Sejarah latar belakang aktuarius yang telah wujud beribu tahun dahulu sebagai pencatat minit senat memberi inspirasi kepada Edward Mores yang menjadi Ketua Pegawai 
Eksekutif yang pertama bagi syarikat Equitable Life pada tahun 1762. Beliau yang menubuhkan syarikat tersebut bersama sekumpulan ahli matematik memilih untuk menggunakan gelaran aktuari bagi merujuk kepada jawatan beliau. Ogborn (1956) berpendapat Mores memilih gelaran aktuari ini memandangkan tugas utama Ketua Pegawai Eksekutif Equitable Life ialah mendaftarkan polisi insurans yang diterima oleh syarikat berkenaan. ${ }^{8}$ Sejak daripada itu gelaran aktuari menjadi sinonim dengan insurans hayat. Walaupun pada dasarnya jawatan aktuarius sebagai pencatat minit mesyuarat senat Rom tidak berkaitan dengan peranan aktuari di era moden; tetapi sumbangan Domitius Ulpianus dalam menghasilkan jadual kemortalan boleh dianggap sebagai titik permulaan bidang sains aktuari.

Gelaran aktuari yang merujuk kepada seorang ahli matematik di dalam insurans hayat menjadi lebih signifikan apabila William Morgan dilantik sebagai aktuari di Equitable Life pada tahun 1775 dan kekal memegang jawatan tersebut selama 55 tahun. Morgan telah memperkenalkan teknik beraktuari dengan menggunakan kepakaran matematik yang ada padanya dalam menjalankan penilaian beraktuari bagi menentukan kedudukan kewangan syarikat untuk memenuhi tuntutan kematian dalam jangka masa panjang. Penilaian aktuari ini dapat mengenal pasti lebihan di mana pendapatan kutipan premium adalah melebihi jangkaan tahap tuntutan kematian berdasarkan jadual kemortalan. Sumbangan Morgan dalam memperkenalkan penilaian aktuari menjadikan beliau dikenali sebagai Bapa Sains Aktuari Moden.

\section{Aktuarius di dalam setiap rejimen ketenteraan}

Kumpulan praetorian prefect merupakan kumpulan pegawai tertinggi kerajaan dalam Empayar Rom yang menjalankan urusan pentadbiran dan perundangan. Kumpulan ini diwujudkan semasa zaman pemerintahan Maharaja Rom Purba, Augustus (63 Sebelum Masehi-14 Masehi) dan terus kekal sehingga kewujudan Empayar Rom Timur.

Kod Undang-undang Rom seperti yang diterjemahkan oleh Blume (1952) menjelaskan secara terperinci tugas pegawai-pegawai tertinggi kerajaan dalam kumpulan praetorian prefect ini. ${ }^{9}$ Selain daripada aktuarius, pegawai-pegawai tertinggi kerajaan Empayar Rom ialah numerarius (ketua akauntan), chartularius (pemegang rekod kerajaan) dan hakim. Dokumen ini menjelaskan bahawa aktuarius juga merupakan seorang akauntan tetapi perbezaan antara aktuarius dan numerarius ialah aktuaris dipertanggungjawabkan dalam menguruskan akaun setiap rejimen ketenteraan dan akaun bagi setiap tentera di dalam rejimen tersebut. Di dalam konteks ini aktuarius marupakan akauntan tentera, sedangkan numerarius adalah akauntan yang menguruskan akaun berkaitan pentadbiran fiskal. Walau bagaimanapun kedua-dua jawatan penting ini, aktuarius dan numerarius saling berhubung satu sama lain kerana kedua-duanya terlibat dalam pengurusan akaun dan kewangan.

Jawatan aktuarius ini terdapat dalam setiap rejimen ketenteraan dari zaman lewat Empayar Rom Purba sehinggalah ke zaman Empayar Rom Timur. Penemuan artefak Empayar Rom di Dura-Europos (bertempat di padang gurun moden Syria) menunjukkan terdapat jawatan aktuarius di wilayah-wilayah jajahan Empayar Rom Timur. Artefak ini yang merupakan sekeping jubin mempunyai potret seorang lelaki bernama Heliodoros dengan jawatan sebagai aktuarius di wilayah itu di sekitar tahun 200-256 Masehi. ${ }^{10}$

Treadgold (1998) membincangkan struktur ketenteraan di zaman lewat Empayar Rom Purba dengan memberi contoh rejimen ketenteraan di bawah Maharaja Diocletian (245-311 Masehi) dan struktur ketenteraan di zaman Empayar Rom Timur dengan memberi contoh rejimen ketenteraan di bawah pemerintahan Maharaja Maurice (539-602 Masehi). ${ }^{11}$ Jika dilihat struktur ketenteraan bagi kedua-dua rejimen ketenteraan yang berlainan zaman ini, terdapat jawatan aktuarius di dalamnya. 
Jadual 1 menunjukkan struktur ketenteraan bagi pasukan rejimen infantri di zaman Empayar Rom Purba di bawah pemerintahan Maharaja Diocletian.

Jadual 1: Struktur bagi Pasukan Rejimen Infantri di Zaman Empayar Rom Purba

\begin{tabular}{|c|l|}
\hline Bilangan & \multicolumn{1}{|c|}{ Pasukan } \\
\hline 1 & Tribune (komander rejimen) \\
\hline 1 & Vicarius (timbalan komander rejimen) \\
\hline 1 & Primicerius (ketua pentadbiran rejimen) \\
\hline 1 & Adjutor (pembantu pentadbiran atau kerani) \\
\hline 6 & Centurions (setiap pegawai mengawasi 80 orang tentera) \\
\hline 1 & Campidoctor (pegawai jurulatih) \\
\hline 1 & Actuarius (aktuarius) \\
\hline 1 & Optio (pegawai pemerintah kedua membantu centurions) \\
\hline 1 & Surgeon (doktor) \\
\hline 2 & Heralds (penyampai maklumat) \\
\hline 2 & Draconarii (pembawa bendera) \\
\hline 1 & Cape bearer (pembawa jubah komander rejimen) \\
\hline 1 & Trumpeter (pemain trompet) \\
\hline 1 & Drummer (pemain drum) \\
\hline 60 & $\begin{array}{l}\text { Decurions (ketua skuad yang terdiri daripada 8 orang tentera bagi setiap } \\
\text { skuad) }\end{array}$ \\
\hline 420 & Common soldiers (Tentera biasa) \\
\hline
\end{tabular}

Sumber: W. Treadgold, Byzantium and Its Army, Stanford, CA: Stanford University Press, 1998.

Di zaman Empayar Rom Timur, struktur ketenteraan bagi sesebuah rejimen infantri tidak banyak bezanya seperti di zaman Empayar Rom Purba. Setiap rejimen masih diketuai oleh seorang tribune (komander rejimen) dan terdiri daripada pegawai-pegawai seperti: seorang vicarius, primicerius, adjutor, aampidoctor, actuarius, optio, surgeon, cape bearer, trumpeter dan drummer; serta dua orang heralds dan draconarii. Perbezaannya ialah rejimen ini mempunya 5 orang hecatontarchs ${ }^{12}$ yang ditugaskan mengawasi 100 orang tentera, berbanding rejimen di zaman Empayar Rom Purba yang mempunyai 6 orang centurions ditugaskan bagi mengawasi 80 orang tentera. Jawatan decurions di zaman Empayar Rom Timur juga telah dimansuhkan dan digantikan dengan tiga jawatan lain iaitu: 50 orang decarchs (ketua skuad yang terdiri daripada 10 orang tentera bagi setiap skuad), 50 orang pentarchs (ketua skuad yang terdiri daripada 5 orang tentera bagi setiap skuad), dan 50 orang tetrarchs (ketua skuad yang terdiri daripada 4 orang tentera bagi setiap skuad). Bilangan common soldiers di zaman Empayar Rom Timur kini telah dikurangkan kepada 350 orang.

Di zaman lewat Empayar Rom Purba, jawatan aktuarius dikaitkan sebagai pengurus kewangan bagi setiap rejimen; dan seterusnya di zaman Empayar Rom Timur, jawatan aktuarius bukan sahaja sebagai pengurus kewangan tetapi peranannya turut diperluaskan di dalam urusan pengagihan gaji tentera-tentera Rom dan peruntukan ketenteraan mereka. Dalam kapasiti ini, tugas aktuarius ini terkandung dalam teks-teks ketenteraan Rom yang dikenali sebagai Taktikon Uspensky yang ditulis sekitar tahun 842 Masehi dan kemudianya di dalam Kletorologion of Philotheos pada tahun 899 Masehi. $^{13}$

Sejarah latar belakang aktuarius yang telah wujud beribu tahun dahulu sebagai salah seorang pegawai penting di setiap rejimen ketenteraan yang dipertanggungjawabkan dalam 
pengurusan kewangan, pengagihan gaji serta peruntukan kepada tentera Rom menunjukkan kepentingan ilmu aktuari dalam konteks sesebuah negara. Selain daripada itu, aktuarius juga terlibat dalam urusan pengiraan kadar cukai yang dikenakan kepada tentera. ${ }^{14}$ Cukai ini dikutip oleh susceptor yang merupakan pemungut cukai dan seterusnya diserahkan kepada aktuarius.

\section{Perkhidmatan Aktuari Pada Era Moden}

Sejarah telah menunjukkan profesion aktuari merupakan salah satu profesion tertua di dunia yang telah wujud sejak zaman Empayar Rom. Beratus tahun selepas itu gelaran aktuari dihidupkan semula oleh Edward Mores bagi merujuk kepada profesion beliau sebagai ahli matematik dalam sebuah syarikat insurans hayat. Sejak itu, profesion aktuari dikaitkan dengan bidang insurans hayat dan seterusnya aktuari mula memasuki bidang-bidang tradisional yang lain seperti insurans am, bidang pencen, keselamatan sosial dan bidang pelaburan.

Kemahiran yang dimiliki oleh aktuari dalam mengaplikasikan teori dan kaedah matematik dan statistik membawa kepada permintaan yang tinggi oleh industri-industri lain di luar bidang tradisional. Kini, sains aktuari telah mula menerokai bidang-bidang nontradisional yang merangkumi pelbagai bidang termasuk kehakiman dan perundangan, ekonomi alam sekitar dan industri sains angkasa.

Di negara-negara maju, aktuari juga diberi kepercayaan dalam menjawat jawatan sebagai pegawai tertinggi kerajaan yang memainkan peranan penting sebagai penasihat kepada kepimpinan kerajaan untuk menggubal dasar dan polisi awam yang berkaitan dengan ekonomi dan sosial. Sebagai mana pentingnya jawatan aktuarius di zaman kerajaan Empayar Rom, pada hari ini aktuari bukan saja diperlukan dalam memenuhi kerja-kerja tradisional dan non-tradisional aktuari, tetapi kepakaran ilmu aktuari diperlukan dalam pembangunan dan memajukan negara.

\section{Aktuari Kerajaan}

Aktuari Kerajaan ialah istilah yang biasa digunakan di kebanyakan negara seperti United Kingdom, Amerika Syarikat, Kanada dan Australia yang merujuk kepada jawatan penting di dalam pentadbiran negara. Peranan Aktuari Kerajaan ini tidak terhad dalam memberikan nasihat dalam perkara-perkara berkaitan dengan bidang insurans, pencen, keselamatan sosial atau pelaburan, tetapi lebih daripada itu memainkan peranan sebagai penasihat kepada kepimpinan kerajaan dalam menggubal dasar dan polisi awam berkaitan ekonomi dan sosial.

Kepentingan aktuari di sektor awam dapat dilihat di United Kingdom seawal tahun 1821 apabila jawatan aktuari diwujudkan di Pejabat Hutang Negara. Ini merupakan jawatan pertama aktuari di sektor awam di United Kingdom. John Finlaison yang merupakan Presiden pertama Institute of Actuaries England ${ }^{15}$ telah dilantik untuk memegang jawatan tersebut. ${ }^{16}$ Sejak itu banyak jawatan aktuari diwujudkan di pejabat-pejabat kerajaan termasuk di Bank Imperial England. Surat Ikatan Perjanjian Bank Imperial England yang diluluskan oleh Parlimen pada tahun 1837 menyatakan "Bahawa pegawai-pegawai utama Bank Imperial England hendaklah sentiasa terdiri daripada enam belas pengarah, tiga orang juruaudit, tujuh pemegang amanah, dan seorang aktuari.”

Pada tahun 1917, jawatan Aktuari Kerajaan diwujudkan di United Kingdom dan seterusnya Jabatan Aktuari Kerajaan United Kingdom ditubuhkan pada tahun 1919. Sejak penubuhannya, sebarang dasar kerajaan yang berkaitan dengan pencen, skim insurans kesihatan kebangsaan, masalah pengangguran dan sebagainya perlu diiringi dengan laporan daripada Aktuari Kerajaan yang memperincikan implikasi kewangan apabila dibahaskan di Parlimen. Peranan Jabatan Aktuari Kerajaan United Kingdom semakin berkembang apabila ia bertindak sebagai penasihat kepada kerajaan, semua jabatan kerajaan serta agensi- 
agensinya. Aktuari Kerajaan bertanggungjawab dalam memberi nasihat kepakaran ilmu aktuari dalam isu-isu berkaitan pelan insurans, skim pencen dan keselamatan sosial negara, pengurusan risiko dan pelaburan oleh agensi-agensi kerajaan serta memberi khidmat analisis statistik dan pemodelan aktuari. Jabatan ini mempunyai kuasa autonomi dan tidak tertakluk kepada mana-mana kementerian. Ini membolehkan Aktuari Kerajaan memberikan nasihat kepakaran ilmu aktuari secara bebas kepada mana-mana kementerian, jabatan kerajaan dan agensi-agensi kerajaan yang lain.

Di Amerika Syarikat, jawatan Aktuari Kerajaan Amerika Syarikat diwujudkan pada tahun 1881 di bawah Jabatan Perbendaharaan. Seorang aktuari bertauliah bernama Ezekiel Elliott dilantik sebagai Aktuari Kerajaan Amerika Syarikat yang pertama. Menurut Myers (1954), tugas Ezekiel tidak terhad hanya berkaitan pengawal seliaan insurans dan menguruskan pelaburan seperti bon kerajaan, tetapi sebagai Aktuari Kerajaan Amerika Syarikat, beliau turut terlibat dalam menguruskan hutang negara, menggunakan analisis matematik dalam menetapkan tarif dan cukai, pengurusan sistem mata wang sehingga kepada kajian kesan kuantitatif terhadap perbendaharaan bagi semua dasar dan polisi awam. ${ }^{17}$

Kini peranan Aktuari Kerajaan di Amerika Syarikat semakin berkembang dan merentasi pelbagai jabatan kerajaan di Amerika Syarikat - pada peringkat kerajaan Persekutuan dan juga kerajaan Negeri. Kebanyakan jabatan kerajaan ini mempunyai Pejabat Ketua Aktuari yang diketuai oleh seorang Ketua Aktuari dan terdiri daripada aktuari bertauliah dan saintis aktuari. Antara jabatan kerajaan yang mempunyai Pejabat Ketua Aktuari ialah Jabatan Perbendaharan, Jabatan Pertahanan, Pentadbiran Keselamatan Sosial, Jabatan Buruh, Pejabat Pengurusan Personel, Pusat Perkhidmatan Medicare dan Medicaid, Perkhidmatan Kesihatan Awam, Jabatan Hal Ehwal Veteran, Pejabat Perakaunan Am, Jabatan Perumahan dan Pembangunan Bandar, Jabatan Tenaga, Lembaga Persaraan Kereta Api, Pejabat Bandaraya New York (di bawah kerajaan Negeri) dan sebagainya.

Sebagai contoh di peringkat kerajaan Persekutuan, terdapat Ketua Aktuari di Jabatan Pertahanan Amerika Syarikat yang bertanggungjawab dalam memberikan nasihat kepakaran berkaitan anggaran kos ketenteraan, membuat unjuran kakitangan ketenteraan dan anggaran perbelanjaannya, menjalankan penilaian terhadap sistem persaraan tentera, pengiraan kadar caruman dan faedah, pelan kesihatan bagi pesara tentera, serta anggaran kos pendidikan dan latihan ketenteraan.

Di peringkat kerajaan negeri seperti mana di bandaraya New York, terdapat Pejabat Aktuari yang memberikan perkhidmatan aktuari dalam sistem persaraan kakitangan Pejabat Bandaraya New York, sistem persaraan bagi kakitangan pendidikan, kumpulan wang pencen polis dan dana pencen Jabatan Bomba. Selain daripada itu pejabat ini yang diketuai oleh seorang Ketua Aktuari juga dipertanggungjawabkan dalam memberikan perkhidmatan aktuari untuk program kesihatan Bandaraya New York, pelan insurans berkelompok dan sebagainya. Kepentingan jawatan ini di New York dapat dilihat apabila Dunlap (1989) melaporkan di dalam akhbar the New York Times bahawa gaji yang diberikan kepada seorang Ketua Aktuari adalah yang tertinggi diberikan kepada kakitangan Bandaraya New York iaitu sebanyak AS\$175,000 setahun - lebih tinggi daripada gaji yang diberikan kepada Datuk Bandar Bandaraya New York. $^{18}$

Secara ringkasnya, Ketua Aktuari di sesebuah jabatan kerajaan di Amerika Syarikat berperanan sebagai penasihat bagi perkara yang berkaitan dengan kepakaran ilmu aktuari dalam konteks jabatan itu sahaja. Ini bermakna terdapat ramai Aktuari Kerajaan di Pejabat Ketua Aktuari merentasi pelbagai jabatan di Amerika Syarikat. Dengan adanya Pejabat Ketua Aktuari di beberapa jabatan penting kerajaan di Amerika Syarikat menunjukkan betapa pentingnya peranan aktuari dalam merangka dasar dan polisi awam.

Contoh-contoh di atas jelas menunjukkan pada era moden ini kepakaran aktuari diperlukan secara meluas oleh jabatan-jabatan kerajaan dan agensi-agensinya dalam 
menyelesaikan isu-isu kewangan serta memainkan peranan penting dalam merangka dasar dan polisi awam.

\section{Bidang-bidang Non-tradisional}

Saintis aktuari yang menggunakan kepakaran matematik, statistik, teori kebarangkalian dan ekonomi turut diperlukan oleh agensi-agensi kerajaan dalam pelbagai bidang seperti bidang kehakiman dan perundangan, ekonomi alam sekitar dan industri sains angkasa.

\section{Kehakiman dan Perundangan}

Selama lebih satu dekad kepakaran ilmu aktuari terbukti diperlukan di dalam bidang kehakiman dan perundangan. Di United Kingdom sebelum tahun 1999, hakim-hakim di negara tersebut yang mengendalikan kes-kes kecederaan peribadi dan litigasi kematian salah memberi penghakiman dengan tidak berdasarkan kepada pengiraan matematik yang mempunyai logik ekonomi.

Seorang peguam, Sir Michael Ogden yang juga merupakan pengerusi Lembaga Pampasan Kecederaan Jenayah United Kingdom bagi tahun 1975 hingga 1989 melihat ketidakadilan sistem pampasan bagi kes-kes kecederaan peribadi dan litigasi kematian salah. Prinsip pampasan bagi kecederaan peribadi dan kematian adalah untuk meletakkan plaintif kembali pada kedudukan kewangannya sebelum terjadinya kemalangan. Ini adalah asas kepada insurans dan pengiraannya perlu kepada asas matematik beraktuari dan matematik kewangan. Kepakaran ilmu aktuari dilihat amat diperlukan dalam membuat pengiraan bagi menghasilkan pengganda untuk digunakan dalam penghakiman. Justeru itu, Ogden melobi di peringkat tertinggi perkhidmatan awam United Kingdom dan badan kehakiman untuk mengkaji pengiraan pampasan dari aspek kehilangan pendapatan masa depan sebagai asas kepada penghakiman. Akhirnya, kerajaan United Kingdom menubuhkan sebuah jawatankuasa bersama yang terdiri daripada aktuari bertauliah dan peguam untuk mengkaji perkara ini dan diketuai oleh Ogden sendiri. Pada tahun 1984, jawatankuasa ini akhirnya menghasilkan satu set jadual statistik iaitu jadual pengganda yang dinamakan Jadual Aktuari dengan nota penjelasan untuk digunakan dalam Kecederaan Peribadi dan Kematian Salah atau singkatannya Jadual Ogden.

Penggunaan Jadual Ogden ini dikuatkuasakan penggunaannya untuk kegunaan hakimhakim di United Kingdom pada tahun 1999. Ini bermakna penghakiman bagi kes-kes kecederaan peribadi dan litigasi kematian perlu menggunakan kaedah beraktuari dengan pengganda yang disediakan di dalam Jadual Ogden. Ini membawa kepada pengiktirafan kepakaran ilmu aktuari dalam bidang kehakiman dan perundangan di United Kingdom.

\section{Ekonomi Alam Sekitar}

Ekonomi alam sekitar merupakan bidang baru yang diterokai oleh aktuari bertauliah dan saintis aktuari. Bidang ini dipelopori oleh aktuari-aktuari bertauliah dari Australian Institute of Actuaries yang terlibat secara aktif dalam isu-isu perubahan iklim melalui kerjasama dengan pihak kerajaan dan penanggung insurans am.

Dalam bidang ekonomi alam sekitar ini, kepakaran ilmu aktuari diperlukan dalam membuat analisis kuantitatif apabila data tidak menentu dan sukar diperoleh, membangunkan model-model matematik bagi fenomena-fenomena alam sekitar, membuat penilaian risiko jangka panjang dan pengiraan kos bagi pemindahan risiko dan menganggarkan modal yang mencukupi bagi kemampanan alam sekitar

Di Australia, satu jawatan yang dikenali sebagai Aktuari Kemampanan Alam Sekitar diwujudkan oleh kerajaa. Sebagai contoh oleh Majlis Bandaraya Tasik Macquarie bagi mengenal pasti risiko-risiko kemampanan alam sekitar dan kaedah-kaedah untuk menguruskannya. Ini menunjukkan penglibatan aktuari bertauliah dan saintis aktuari dalam 
bidang ekonomi alam sekitar ini bukan sahaja melalui penyelidikan di atas kertas tetapi telah dipraktikkan dengan wujudnya jawatan-jawatan seperti penganalisis alam sekitar dan aktuari kemampanan alam sekitar yang berkhidmat dengan pihak kerajaan.

\section{Industri Sains Angkasa}

Penggunaan teknik beraktuari turut diperlukan dalam pengurusan risiko sains angkasa merangkumi risiko kelamatan kemanusiaan (tenaga kerja dan orang awam), risiko keselamatan alam sekitar dan risiko kerosakan harta benda dan peralatan. NASA atau nama penuhnya Pentadbiran Aeronautik dan Angkasa Lepas Kebangsaan Amerika yang merupakan sebuah agensi kerajaan Amerika Syarikat mula mengikhtiraf kepakaran aktuari dalam program sains angkasa mereka. Buku A Risk Reduction Strategy for Human Exploration of Space: A Review of NASA's Bioastronautics Roadmap yang merupakan hasil kajian Institute of Medicine dan National Research Council, antaranya mencadangkan penggunaan kaedah aktuari dalam membuat penilaian risiko kesihatan angkasawan semasa misi penerokaan angkasa lepas dijalankan. Kaedah aktuari ini digunakan terutamanya apabila data adalah tidak lengkap. Kaedah aktuari boleh menyelesaikan masalah ini dengan menyesuaikan data daripada sumber lain seperti data daripada kajian longitudinal kesihatan angkasawan yang dijalankan oleh Pusat Angkasa Lepas Johnson Amerika Syarikat. Seterusnya pemodelan aktuari dibangunkan untuk menganggar kemungkinan berlakunya perubahan kesihatan intrinsik bagi anak-anak kapal dalam misi penerokaan angkasa lepas. Maklumat ini seterusnya digunakan sebagai salah satu kriteria pemilihan angkasawan untuk menyertai sesuatu misi.

\section{Perkhidmatan Aktuari di Malaysia}

Di Malaysia, sejarah penubuhan perkhidmatan aktuari bermula pada tahun 1964 melalui Surat Pekeliling Am Bil. 6 dan 6A tahun 1964: Kuasa-kuasa yang Melaksanakan di bawah Pewujudan Aktuari. Pada ketika itu, Kerajaan Persekutuan Malaysia melantik seorang aktuari bertauliah bernama J.R. Ford sebagai Ketua Perkhidmatan Aktuari. Pada awal penubuhannya, Unit Perkhidmatan Aktuari yang diletakkan di bawah Jabatan Perdana Menteri dan berperanan untuk membantu kerajaan dalam merangka dasar dan polisi awam serta menawarkan khidmat rundingan dalam perkara yang berkaitan dengan pencen dan persaraan serta isu kewangan lain. Jadual 2 menunjukkan Aktuari yang mengetuai Unit Perkhidmatan Aktuari merupakan antara jabatan-jabatan kerajaan di bawah Jabatan Perdana Menteri semasa zaman pemerintahan Yang Amat Berbahagia Tun Abdul Razak Hussein sebagai Perdana Menteri Malaysia yang kedua. 
Jadual 2: Jabatan Kerajaan di bawah Jabatan Perdana Menteri pada tahun 1971

\begin{tabular}{|l|l|}
\hline & \multicolumn{1}{|c|}{ Senarai Jabatan } \\
\hline 1. & Sekretariat Kabinet \\
\hline 2. & Jabatan Perpaduan Negara \\
\hline 3. & Jabatan Perpaduan Negara \\
\hline 4. & Unit Perancangan Ekonomi \\
\hline 5. & Unit Pentadbiran Pembangunan \\
\hline 6. & Bahagian Pentadbiran dan Kewangan \\
\hline 7. & Bahagian Istiadat \\
\hline 8. & Bahagian Penyelidikan \\
\hline 9. & Pusat Pengajian Pembangunan Malaysia \\
\hline 10. & Aktuari \\
\hline 11. & Majlis Muhibbah Negara \\
\hline 12. & Jabatan Perkhidmatan Awam Persekutuan \\
\hline 13. & Kementerian Dalam Negeri Sarawak \\
\hline 14. & Pejabat Setiausaha Persekutuan, Sabah \\
\hline 15. & Suruhanjaya Perkhidmatan Awam Persekutuan \\
\hline 16. & Jabatan Perangkaan \\
\hline 17. & Suruhanjaya Pilihan Raya \\
\hline 18. & Biro Terjemahan Persekutuan \\
\hline 19. & Arkib Negara \\
\hline 20. & Muzium Negara \\
\hline 21. & Lembaga Tabung Haji \\
\hline
\end{tabular}

Sumber: Federal Department of Information, Malaysia Year Book 1971, Kuala Lumpur: Malay Mail Publication.

Seterusnya pada 1 Februari 1976, Unit Perkhidmatan Aktuari dipindahkan ke Bahagian Pencen di bawah kawalan Jabatan Perkhidmatan Awam. Ini bermakna Unit Perkhidmatan Aktuari telah diperkecil fungsi dan peranannya daripada turut terlibat dengan perangkaan dasar dan polisi awam kepada hanya memberi khidmat rundingan bagi perkara yang berkaitan dengan skim pencen dan persaraan seperti yang terkandung di dalam Surat Pekeliling Am Bil. 2 tahun 1989. Pada 1 Januari 1993 pula, Unit Perkhidmatan Aktuari ditempatkan di bawah Kementerian Kewangan melalui Surat Pekeliling Perbendaharaan Bil. 3 Tahun 1996. Seterusnya pada tahun 2001, fungsi dan peranan unit ini menjadi semakin kecil apabila dijadikan sebuah unit di bawah Bahagian Pengurusan Pinjaman, Pasaran Kewangan dan Aktuari di Kementerian Kewangan.

Apabila Skim Baru Perkhidmatan Awam (SBPA) diperkenalkan untuk dilaksana berkuat kuasa pada 1 Januari 2012, Unit Perknidmatan Aktuari tersenarai antara 78 skim perkhidmatan yang dijumudkan. Perkhidmatan jumud bermaksud perkhidmatan yang tidak lagi diperlukan atas sebab-sebab seperti fungsi yang tidak relevan, fungsi yang boleh diambil alih oleh skim perkidmatan yang lain atau fungsi yang boleh diswastakan dan dialih daya. Kira-kira tiga bulan selepas itu, apabila SBPA dibatalkan dan kerajaan mengekalkan Skim Saraan Malaysia (SSM) yang ditambah baik, Unit Perkhidmatan Aktuari kembali kepada status awal sebelum dijumudkan iaitu kekal di bawah Kementerian Kewangan sebagai sebuah unit di Bahagian Pengurusan Pinjaman, Pasaran Kewangan Dan Aktuari. Walau bagaimanapun pada tahun 2014, Unit Perkhidmatan Aktuari ini akhirnya telah dijumudkan. 
Di era kemodenan ini, apabila negara-negara maju terus mengikhtiraf aktuari sebagai pegawai tertinggi kerajaan yang memainkan peranan penting dalam memajukan negara, sebaliknya di Malaysia peranan aktuari terus diketepikan. Apabila kerajaan menjumudkan Unit Perkhidmatan Aktuari yang telah berusia 50 tahun ini bermakna kepentingan ilmu aktuari itu seolah-olah tidak diperlukan oleh kerajaan dalam membantu pentadbiran negara.

\section{Persatuan Aktuari Malaysia}

Pentauliahan aktuari memerlukan seseorang itu lulus dalam satu siri peperiksaan tahap profesional yang ketat dan mengambil masa beberapa tahun untuk dilengkapkan sebelum boleh diterima sebagai Ahli Bersekutu dan seterusnya Felo di dalam sesebuah badan ikhtisas aktuari. Di bawah Akta Insurans 1996 dan Akta Takaful 1984, Malaysia mengikhtiraf aktuari yang merupakan ahli daripada badan-badan ikhtisas berikut: Institute of Actuaries England, Faculty of Actuaries Scotland, Society of Actuaries of the United States of America, Institute of Actuaries Canada dan Institute of Actuaries Australia.

Malaysia mempunyai badan profesional aktuari yang dikenali sebagai Persatuan Aktuari Malaysia bagi mewakili profesion aktuari di negara ini. Persatuan yang ditubuhkan pada 5 Oktober 1978 ini menjadi platform untuk ahli-ahli membincangkan isu-isu berkaitan amalan aktuari, pembangunan profesional dan juga memberi sokongan pendidikan kepada pelajar untuk menjadi aktuari bertauliah. Persatuan Aktuari Malaysia telah diterima sebagai ahli penuh International Actuarial Association pada 20 Oktober 2003. Walau bagaimanapun Persatuan Aktuari Malaysia tidak menawarkan peperiksaan profesional tempatan bagi profesional aktuari, tetapi sebaliknya keahlian adalah berdasarkan pentauliahan badan-badan aktuari yang diikhtiraf. Sebagai contoh untuk diterima keahlian sebagai ahli Felo Persatuan Aktuari Malaysia, seseorang itu perlu mempunyai kelayakan sebagai Felo salah satu daripada badan ikhtisas aktuari seperti yang disenaraikan di atas.

Mengikut statistik daripada Persatuan Aktuari Malaysia (2015) setakat pada 31 Disember 2014, terdapat seramai 121 orang ahli Felo, 45 orang orang Ahli Bersekutu, 504 Ahli Biasa dan 38 orang di bawah kategori pelajar berdaftar dengan badan tersebut. Bilangan ahli Felo yang berdaftar dengan Persatuan Aktuari Malaysia boleh dikatakan mewakili bilangan aktuari bertauliah berkelayakan Felo di Malaysia. Pada tahun 2002, statistik Persatuan Aktuari Malaysia menunjukkan Malaysia hanya mempunyai 40 orang ahli Felo yang berdaftar dengan badan itu. Dalam tempoh 12 tahun, bilangan ini telah meningkat 3 kali ganda (atau 302.5 peratus) bilangannya berbanding pada tahun $2002 .{ }^{19}$

Pertambahan bilangan aktuari bertauliah di peringkat ahli Felo dan ahli yang berdaftar dengan Persatuan Aktuari Malaysia menunjukkan profesion ini semakin penting di Malaysia. Pada masa hadapan dijangkakan bilangan aktuari bertauliah di Malaysia akan bertambah dan permintaan bagi profesion ini akan semakin meningkat merintasi bidang-bidang tradisional dan non-tradisional di sektor swasta. Di sektor swasta, misalnya di syarikat-syarikat insurans, ramai aktuari bertauliah dipertanggungjawabkan menjawat jawatan-jawatan penting seperti Ketua Pegawai Eksekutif, Ketua Pegawai Kewangan, Ketua Pegawai Risiko dan sebagainya. Justeru itu, jika pelbagai bidang di dalam sektor swasta mengikhtiraf kepakaran aktuari dalam menggunakan kemahiran matematik untuk mengenalpasti, menganalisis, dan menyelesaikan masalah perniagaan mahupun sosial melalui aplikasi kebarangkalian, statistik, teori risiko dan prinsip-prinsip kewangan; mengapa sektor awam tidak memberikan kepercayaan kepada mereka untuk sama-sama berkhidmat memajukan negara. Dengan kepercayaan yang diberikan sudah pasti profesion aktuari dapat memberi sumbangan besar dalam memajukan negara. Sebagai mana di zaman lewat Empayar Rom Purba terdapat seorang aktuarius ditempatkan di setiap pasukan rejimen infantri untuk menguruskan hal-ehwal kewangan bagi setiap rejimen, ianya boleh diandaikan perlunya kepakaran ilmu aktuari di setiap jabatan kerajaan di Malaysia dalam membantu menyelesaikan pelbagai isu kewangan. Selain 
daripada itu kemahiran matematik dan analisis statistik yang dimiliki leh aktuari boleh digunakan dalam membuat perkiraan kesan kuantitatif dalam menilai sesuatu dasar atau polisi awam.

\section{Perkembangan Pendidikan Sains Aktuari di Malaysia}

Seperti yang dinyatakan di bahagian 4.0, sejarah telah menunjukkan bidang sains aktuari bukanlah suatu bidang yang baru di Malaysia apabila perhidmatan aktuari ditubuhkan oleh Kerajaan Persekutuan Malaysia pada tahun 1964.

Di dalam bidang pendidikan sains aktuari, Institut Teknologi MARA (ITM) ${ }^{20}$ telah mula menawarkan program sains aktuari seawal tahun 1966 di bawah Sekolah Sains Aktuari, Statistik, Matematik, Ekonometrik dan Sibernetik (School of Actuarial Science, Statistics, Mathematics, Economics and Cybernatics atau singkatannya ASMEC) di ITM Kampus Jalan Othman, Petaling Jaya. Program yang ditawarkan pada ketika itu adalah program profesional luaran daripada Institute of Actuaries England. Pada tahun 1969, ITM telah memperkenalkan program dalaman dan lahirlah program Diploma Sains Aktuari iaitu program diploma dengan tempoh pengajian selama 4 tahun setaraf dengan ijazah am. Seterusnya pada tahun 1974, ASMEC ditukarkan nama kepada Kajian Sains Matematik dan Komputer. Sekali lagi namanya ditukarkan apabila ITM dinaik taraf menjadi sebuah universiti dan dikenali sebagai Fakulti Teknologi Maklumat dan Sains Kuantitatif pada tahun 1997. Kini, fakulti ini dikenali sebagai Fakuti Sains Komputer dan Matematik yang menawarkan pelbagai program di peringkat Diploma, Ijazah Sarjana Muda dan pasca siswazah dalam bidang sains aktuari. UiTM juga telah berjaya melahirkan graduan Ijazah Kedoktoran dalam bidang sains aktuari.

Universiti Kebangsaan Malaysia (UKM) menjadi universiti tempatan kedua yang menawarkan program sains aktuari apabila program Ijazah Sarjana Muda Sains dengan kepujian Sains Aktuari mula ditawarkan pada tahun 1988, yang pada ketika itu di bawah Jabatan Statistik, Pusat Pengajian Kuantitatif. Program sains aktuari di UKM pada ketika ini dikendalikan di bawah Pusat Pengajian Sains Matematik, Fakulti Sains dan Teknologi.

Masa berlalu dan perkembangan pendidikan sains aktuari di Malaysia berkembang dengan amat pantas terutamanya selepas tahun 2000. Universiti Sains Islam Malaysia (USIM) mula menawarkan program Ijazah Sarjana Muda Sains dengan kepujian dalam bidang Sains Aktuari dan Pengurusan Risiko di bawah Fakulti Sains dan Teknologi pada tahun 2003. Universiti Malaya sebagai universiti tertua Malaysia turut menawarkan program dalam bidang ini yang dikenali sebagai Ijazah Sarjana Muda Sains dengan kepujian Matematik Beraktuari dan Kewangan pada tahun 2005.

Perkembangan pendidikan sains aktuari yang pesat juga dapat dilihat di institusi pendidikan tinggi swasta apabila Universiti Tunku Abdul Rahman (UTAR) mula menawarkan Ijazah Sarjana Muda Sains dengan kepujian Sains Aktuari pada tahun 2009; Universiti UCSI menawarkan program Ijazah Sarjana Muda Sains dengan kepujian Sains Aktuari pada tahun 2010, dan Universiti Sunway pula memulakan program Ijazah Sarjana Muda Sains dengan kepujian Pengajian Aktuari pada tahun 2012, diikuti yang terbaru oleh Universiti Asia Pasifik (APU). Sebuah universiti di United Kingdom yang sering menjadi pilihan pelajar Malaysia melanjutkan pengajian dalam bidang sains aktuari, Heriot-Watt University turut membuka cawangan di Malaysia pada tahun 2014 dan menawarkan program Ijazah Sarjana Muda Sains dengan kepujian Sains Aktuari. Selain daripada itu, beberapa institusi pengajian tinggi swasta turut menawarkan program ijazah pemindahan kredit dalam bidang sains aktuari dengan universiti luar negara seperti Universiti Antarabangsa INTI, Universiti HELP dan Universiti Taylor.

Perkembangan pesat dalam pendidikan sains aktuari di Malaysia adalah disebabkan permintaan tinggi terhadap kerjaya aktuari bertauliah dan saintis aktuari untuk mengisi pelbagai bidang pekerjaan di sektor swasta. Dengan kemahiran yang dimiliki dalam 
permodelan matematik dan membuat analisis dengan menggunakan pelbagai kaedah statistik, graduan sains aktuari bukan sahaja dapat memenuhi permintaan kepakaran ilmu aktuari dalam bidang-bidang tradisional, malah mampu untuk meneroka pelbagai bidang termasuk bidang-bidang non-tradisional seperti kejuruteraan, sains angkasa dan sebagainya. Justeru itu, sektor awam perlu mengikut arah perkembangan ini dengan turut mengikhtiraf kepakaran ilmu aktuari.

\section{Kesimpulan}

Kertas ini telah membincangkan peranan penting aktuari sebagai pegawai tertinggi kerajaan dari perspektif sejarah dan era moden. Sejarah menunjukkan aktuari merupakan satu jawatan penting dalam sesebuah negara sejak beribu tahun dahulu. Sains aktuari bermula sebagai satu cabang matematik pada abad ke-17 apabila permintaan dalam bidang insurans hayat semakin meningkat dan seterusnya gelaran aktuari dihidupkan semula pada abad ke-18. Satu abad berikutnya, jawatan Aktuari Kerajaan pula diwujudkan sebagai satu jawatan tertinggi kerajaan yang dipertanggungjawabkan dalam pengurusan kewangan, perancangan ekonomi dan pelan pembangunan negara yang melibatkan pembentukan dasar dan polisi awam. Di era kemodenan ini, kepakaran ilmu aktuari bukan sahaja diperlukan dalam perkara-perkara yang melibatkan skim insurans, pencen dan keselamatan sosial, tetapi turut diperlukan dalam bidang-bidang non-tradisional. Pelbagai bidang seperti pertahanan, pembangunan bandar, kehakiman dan perundangan, ekonomi alam sekitar, kejuruteraan dan industri sains angkasa juga telah mula mengiktiraf kaedah aktuari sebagai satu cara penyelesaian masalah.

Sejak tahun 2000 bidang sains aktuari berkembang pesat di Malaysia. Ini dapat dilihat dengan pertambahan bilangan aktuari bertauliah dan jumlah ahli-ahli yang berdaftar dengan Persatuan Aktuari Malaysia. Pendidikan dalam bidang aktuari juga berkembang pesat dengan bertambahnya institusi-institusi pengajian tinggi awam dan swasta yang menawarkan program sains aktuari di pelbagai peringkat pengajian. Ini menunjukkan kemahiran ilmu aktuari adalah amat signifikan dan diperlukan dalam pelbagai bidang.

Dalam menuju menjadi negara maju, Malaysia perlu kembali mengiktiraf kemahiran ilmu aktuari. Perkhidmatan aktuari yang telah dimulakan di negara ini setahun selepas penubuhan Persekutuan Malaysia dan telah sama-sama membantu dalam memajukan negara perlu dikembalikan semula. Sebagaimana Empayar Rom yang mempunyai aktuarius sebagai salah seorang pegawai kerajaan yang penting, negara kita juga perlu mempunyai Aktuari Kerajaan sebagai pegawai tertinggi kerajaan - sama penting seperti pegawai tertinggi kerajaan yang lain seperti Ketua Audit Negara yang mengetuai Jabatan Audit Negara, Akauntan Negara yang menerajui Jabatan Akauntan Negara, Gabenor di Bank Negara Malaysia, serta Peguam Negara di Jabatan Peguam Negara.

\section{Nota}

${ }^{1}$ P. Glare, Oxford Latin dictionary. New York: Clarendon Press, 1982.

${ }^{2}$ Di dalam kertas ini perkataan aktuarius digunakan merujuk kepada actuarius.

${ }^{3}$ R. Jebb, Collected Works of Richard Claverhouse Jebb, Vol. 9. Bristol: Thoemmes Press, 2002.

${ }^{4}$ S. Martin, and D. Copeland, The function of newspapers in society: A global perspective. Westport, CT: Praeger Publishers Inc., 2003.

${ }^{5}$ Gelaran jawatan tertinggi dalam Empayar Rom.

${ }^{6}$ W. Mays, “Ulpian's Table”, The Actuary, June 1971, hlm. 1-2.

${ }^{7}$ E. Kopf, "The early history of the annuity”, Proceedings of the Casualty Actuarial Society, 13(27), 1926, hlm. 225-266.

${ }^{8}$ M. Ogborn, “The professional name of actuary”, Journal of the Institute of Actuaries, 82, 1956, hlm. $233-246$. 


\footnotetext{
${ }^{9}$ F. Blume, Annotated Justinian Code, College of Law George William Hopper Law Library, 1952. Retrieved September 01, 2015, from http://www.uwyo.edu/lawlib/blume-justinian/ajc-edition-1

10 Yale University Art Gallery, Ceiling Tile with Heliodoros, an Actuarius, Available at: http://artgallery.yale.edu/collections/objects/5748 (Accessed: 20 Oktober 2015).

${ }^{11} \mathrm{~W}$. Treadgold, Byzantium and Its Army, Stanford, CA: Stanford University Press, 1998.

${ }^{12}$ Terminologi hecatontarchs yang digunakan pada zaman Empayar Rom Timur membawa maksud yang sama seperti centurions yang digunakan dalam struktur ketenteraan di zaman Empayar Rom Purba (Treadgold, 1998).

${ }^{13} \mathrm{~J}$. Bury, The Imperial Administrative System in the Ninth Century: With a Revised Text of Kletorologion of Philotheos (1911), Whitefish, MT: Kessinger Publishing, 2008.

${ }^{14}$ P. Erdkamp, A companion to the Roman army, Oxford: Blackwell Publishing Ltd., 2011.

${ }^{15}$ Institute of Actuaries England ditubuhkan pada tahun 1848 oleh sekumpulan aktuari di syarikat-syarikat insurans hayat yang berpusat di kota London. Ini menjadikan Institute of Actuaries England sebagai badan ikhtisas aktuari yang tertua di dunia. Pada tahun 1856, Faculty of Actuaries Scotland ditubuhkan bertujuan untuk mewakili kepentingan aktuari yang menjalankan amalan aktuari di Scotland. Kedua-dua institusi berkenaan bergabung pada 1 Ogos 2010 dan dikenali sebagai Institute and Faculty of Actuaries United Kingdom.

${ }^{16}$ M. Ogborn, "The professional name of actuary”, Journal of the Institute of Actuaries, 82, 1956.

${ }^{17}$ R. Myers, The first United States Government Actuary and his succesors. Transactions of Society of Actuaries, 1954, hlm. 488-505.

${ }^{18}$ D. Dunlap, “Actuary to Draw New York City's Top Salary”, The New York Times, June 9, 1989.

${ }_{19}$ Persatuan Aktuari Malaysia (2015). Society Statistics-Actuarial Society of Malaysia. Dicapai pada 13 November 2015, daripada http://actuaries.org.my/about/society-statistics/

${ }^{20}$ ITM telah dinaik taraf mejadi Universiti pada tahun 1997 dan kemudiannya dikenali sebagai Universiti Teknologi MARA atau singkatannya UiTM.
} 